RenATA MARCINIAK-FIRADZA

University of Łódź

\title{
Competencies of a deaf educator and deaf speech and language therapist in the diagnostic and therapeutic process of a child with hearing impairment
}

\begin{abstract}
Renata Marciniak-Firadza, Competencies of a deaf educator and deaf speech and language therapist in the diagnostic and therapeutic process of a child with hearing impairment. Interdisciplinary Contexts of Special Pedagogy, no. 25, Poznan 2019. Pp. 297-331. Adam Mickiewicz University Press. ISSN 2300-391X. DOI: https:// doi.org/10.14746/ikps.2019.25.13

The specificity of the cognitive processes of a child with hearing impairment, and the need to apply appropriate methods and means of teaching, requires participation of a properly prepared specialist in the field of remedial and educational, preventive and therapeutic work in the didactic process.

The manifestation of not only theoretical reflection on the profession of teacher and speech and language therapist, but also the effect of practical searches related to the vocational education and training of educators and speech and language therapists, as well as the assessment of their work, is the issue of professional competencies of a deaf educator and deaf speech and language therapist in the diagnostic and therapeutic process of a child with hearing impairment. Competence is understood in the article in two ways: as a range of knowledge, skills, predispositions and as a range of qualifications.
\end{abstract}

KEY WORDS: competence, deaf education, deaf speech and language therapy 


\section{Introduction}

As emphasized by Katarzyna Plutecka, the author of the monograph entitled "Professional competencies of a deaf educator with hearing impairment" ("Kompetencje zawodowe surdopedagoga $z$ wada stuchu"), the specificity of cognitive processes in children deviating from the psychophysical standard, as well as the need to apply appropriate teaching methods and aids require the participation of a specialist properly trained in remedial, educational, preventive and therapeutic work in the didactic process ${ }^{1}$. In the case of children with hearing impairment, the requirements on deaf educators are subordinated to the comprehensive development of the individual with hearing impairment, the ability to communicate the knowledge about the surrounding world, and associated phenomena, their properties and relationships between them, as well as about the cause-effect relationship ${ }^{2}$.

Speech development is inseparably connected to mental development (including intellectual development) and social development of the child. It is not necessary to convince anyone about the importance of communication and intercommunication with other people for each human being. Because the condition for natural and correct development of voice and speech is, among others, the ability to hear ambient sounds, a deaf speech and language therapist plays important role in the process of hearing rehabilitation ${ }^{3}$. The specificity of speech and language therapy interactions related to shaping communication competencies of people with hearing impairment requires a deaf speech and language therapist to have,

${ }^{1}$ K. Plutecka, Kompetencje zawodowe surdopedagoga $z$ wada stuchu, Wydawnictwo Impuls, Cracow 2006, p. 61.

2 A. Korzon, Efektywny surdopedagog w opinii nauczycieli $i$ uczniów z wadą stuchu, (in:) Pedagogika specjalna wobec zagrożeń $i$ wyzwań XXI wieku: materiały z obrad XVI sekcji III Zjazdu Pedagogicznego w Poznaniu (21-23 September 1998), ed. J. Pańczyk, W. Dykcik, Wydawnictwo Naukowe Uniwersytetu im. A. Mickiewicza, Poznań 1999.

${ }^{3}$ Deaf speech and language therapy focuses on the communication specificities of people with hearing impairment and its biopsychosocial conditions. 
among others, the ability to diagnose developmental needs, including communication-related needs of a hearing-impaired child in order to improve them, correct them and compensate for them, which requires the ability to support both the hearing-impaired child and their family.

The right of people with hearing impairment to care (including rehabilitation, education) from the part of the state and various institutions is guaranteed by Polish and international legislation, cf. e.g.

1. The Constitution of the Republic of Poland, which: in art. 68 paragraph 3 states that people for whom public authorities have special obligations regarding the provision of special health care include children and handicapped people. This means that children are entitled to "special health care" for both belonging to a specific age category and their disability status; in Article 69, it is said "Public authorities shall provide, in accordance with statute, aid to disabled persons to ensure their subsistence, adaptation to work and social communication"; in Article 32, point 2 it is stated that "No one shall be discriminated against (...) for any reason whatsoever". The protection of these goods is the responsibility of public authorities.

2. The Act of 19 August 1994 on the protection of mental health (Journal of Laws No. 111, item 535 as amended), which in art. 4 ensures that "preventive actions in the field of mental health protection are taken above all among children..." and that these actions include, in particular, "the establishment of facilities to develop preventive activities, primarily psychological counselling, and specialist facilities covering early recognition of needs of children with psychomotor developmental disorders."

3. The Act of 7 September 1991 on the education system (Journal of Laws of 1996, No. 67, item 329, as amended), which states in the preamble that "Education in the Republic of Poland is a common good of society; is guided by the principles contained in the Constitution of the Republic of Poland, as well as the indications contained in the Universal Declaration of Human Rights, the International Covenant on Civil and Political Rights and the Convention on the Rights of the Child", and in Art. 71b introduces the possibility of 
early support for the development of the child and their family from the moment disability is diagnosed.

4. Convention on the Rights of the Child, which includes the agreement of the countries ratifying the Convention that health care, including rehabilitation and therapy, and education of children with disabilities are covered by the Convention on the Rights of the Child, and in art. 23 1. states that, "States Parties recognize that a mentally or physically disabled child should enjoy a full and decent life, in conditions which ensure dignity, promote self-reliance and facilitate the child's active participation in the community".

An important step was the signing and ratification by Poland of the UN Convention on the Rights of Persons with Disabilities (the Convention on the Rights of Persons with Disabilities adopted by the United Nations General Assembly on December 13, 2006 in New York pursuant to Resolution 61/106; it entered into force on May 3, 2008, Poland signed the Convention on March 30, 2007, and ratified it on September 6, 2012. The Convention has bound Poland in internal and external policies since October 25, 2012, after its publication in Journal of Laws of 2012, item 1169) (hereinafter also referred to as: the Convention), being the first international agreement that comprehensively regulates the rights of people with disabilities and specifies the obligations of the States Parties in respect of their observance and protection. It should be noted that in its provisions the Convention directly refers to the implementation of the rights of deaf people. Article 24 of the Convention states that the necessary actions include:

facilitating the learning of sign language and the promotion of the linguistic identity of the deaf community, [...] ensuring that the education of persons, and in particular children, who are blind, deaf or deafblind, is delivered in the most appropriate languages and modes and means of communication for the individual, and in environments which maximize academic and social development.

It includes a record regarding recognition of the specific cultural and linguistic identity of deaf people, including sign languages and culture of deaf people (art. 30 paragraph 4): 
Persons with disabilities shall be entitled, on an equal basis with others, to recognition and support of their specific cultural and linguistic identity, including sign languages and deaf culture.

In the Convention on the Rights of Persons with Disabilities, Article 24 on education states that in countries that have signed the convention: a) persons with disabilities can access an inclusive, quality and free primary education and secondary education on an equal basis with others in the communities in which they live, on the basis of disability; b) States Parties shall enable persons with disabilities to learn life and social development skills to facilitate their full and equal participation in education and as members of the community; c) it is ensured that the education of persons, and in particular children, who are blind, deaf or deafblind, is delivered in the most appropriate languages and modes and means of communication for the individual, and in environments which maximize academic and social development; d) appropriate measures will be taken to train professionals and staff who work at all levels of education. Such training shall incorporate disability awareness and the use of appropriate augmentative and alternative modes, means and formats of communication, educational techniques and materials to support persons with disabilities.

It should also be mentioned that the problem of hearing loss in schoolchildren and its consequences has been recognized in Europe, as evidenced by the signing of two European Scientific Consensuses on June 22, 2011. The first of them entitled: "Hearing Screening of Pre-school and School-Age Children" was signed by 35 representatives of 27 countries, while the second consensus entitled "Hearing, Vision, and Speech Screening in Pre-School and School-Age Children" was signed by representatives of the scientific community (http://whc.ifps.org.pl/konkluzja-rady/).

In order to ensure the appropriate level of the rehabilitation and education of people with hearing impairment guaranteed by legislation, high-class specialists, including deaf educators and deaf speech and language therapists are needed. 
The manifestation of not only theoretical reflection on the profession of teacher and speech and language therapist, but also the effect of practical searches related to the vocational education and training of educators and speech and language therapists, as well as the assessment of their work, is the issue of professional competencies of a deaf educator and deaf speech and language therapist.

\section{The concept of competence, classification of competencies}

The term "competence" comes from the Latin language, in which competere means 'fit'. The semantic scope of the concept of "competence" can be found in numerous synonymous terms, such as: predisposition, qualification, skill, ability, preparation. In source literature, various definitions of professional competence are found. The first group consists of definitions having an instrumental nature. They recognize competence as a higher order qualification that predisposes the individual to solve problems ${ }^{4}$. In the emotional and normative aspect, competence is an instruction expressing a positive, accepting attitude to specific tasks 5 . The third group of definitions includes those that can be described as comprehensive. In this approach, competence is a dynamic structure and is a function of integrating knowledge, emotions, understanding, desire and behaviour6.

Competence is the range of one's knowledge, skills and responsibility. A competent employee is an employee who is able to

${ }^{4}$ S. Dylak, Wizualizacja w kształceniu nauczycieli, Wydawnictwo Naukowe Uniwersytetu im. A. Mickiewicza, Poznań 1995.

${ }^{5}$ M. Dudzikowa, Kompetencje autokreacyjne - czy i jak sa możliwe do nabycia w toku studiów pedagogicznych, (in:) Ewolucja tożsamości pedagogiki, ed. H. Kwiatkowska, Wydawnictwo IHNOiT, Warsaw 1994.

${ }^{6}$ M. Czerepaniak-Walczak, Aspekty i źródła profesjonalnej refleksji nauczyciela, Wydawnictwo Edytor, Torun 1997; K. Stech, Kompetencje zawodowe nauczyciela spojrzenie na problem, (in:) Kompetencje nauczyciela-wychowawcy, ed. K. Ferenz, E. Kozioł, Wydawnictwo Naukowe Uniwersytetu Zielonogórskiego, Zielona Góra 2002. 
properly perform assigned tasks; he has appropriate competence for their completion 7 . As I. Zeber-Dzikowska, M. Wysocka-Kunisz and A. Szydłowska write, "Competences understood in a standard way are basic requirements for a profession in terms of skills, knowledge and psychophysical features that enable effective performance of typical, characteristic professional tasks. Therefore, the employee's competences can be briefly defined as a set of necessary factors: knowledge, skills and psychophysical predispositions to practice a given profession ${ }^{8}$. Similarly, D. Hyżak believes that: "In the teacher's work, competences are identified with the qualifications necessary for the effective performance of this profession?.

Therefore, competences can be perceived as certain individual abilities of an individual and as qualifications, i.e. normative abilities that a person in the position of a teacher should possess.

Wacław Strykowski draws attention to the fact that the term "competence" can also mean the range of qualifications ${ }^{10}$.

In the field of pedeutology, there are numerous classifications of teaching (pedagogical) competences, cf., among others, classifications of: H. Hamer11, S. Dylak12, K. Stech"13, R. Kwaśnica14, C. Banach $^{15}$ or K. Denek ${ }^{16}$.

7 W. Kopaliński, Słownik wyrazów obcych $i$ zwrotów obcojęzycznych z almanachem, Warsaw 2000, Wydawnictwo Świat Książki, p. 269.

${ }^{8}$ I. Żeber-Dzikowska, M. Wysocka-Kunisz, A. Szydłowska, Kompetencje nauczyciela w kontekście kształcenia, „Społeczeństwo. Edukacja. Język” 2016, no. 4, p. 94.

${ }^{9}$ D. Hyżak, Kompetencje i umiejętności nauczycieli wobec wyzwań XXI wieku, (in:) Edukacja jutra. XI Tatrzańskie Seminarium Naukowe, ed. F. Bereźnicki, K. Denek, Wydawnictwo Uniwersytetu Szczecińskiego, Szczecin 2005, p. 297.

10 W. Strykowski, J. Strykowska, J. Pielachowski, Kompetencje nauczyciela szkoty wspótczesnej, Wydawnictwo eMPi, Poznań 2003, p. 22.

11 H. Hamer, Klucz do efektywności nauczania. Poradnik dla nauczycieli, Wydawnictwo Veda, Warsaw 1994, pp. 25-125.

12 S. Dylak, Wizualizacja w ksztatceniu nauczycieli, Wydawnictwo Naukowe Uniwersytetu im. A. Mickiewicza, Poznań 1995, p. 35.

13 Stech, Kompetencje zawodowe nauczyciela - spojrzenie na problem, (in:) Kompetencje nauczyciela-wychowawcy, ed. K. Ferenz, E. Kozioł, Wydawnictwo Naukowe Uniwersytetu Zielonogórskiego, Zielona Góra 2002, p. 16. 
For the purposes of the present article, the author will use a typology of competences, considering the complexity and multidimensionality of teacher's tasks and the specificity of the teaching profession, presented by the Committee on Education Studies of the Polish Academy of Sciences. In this typology certain general standards for teachers' activities are distinguished, while the detailed intellectual and practical skills are grouped into categories of the following competences:

- praxeological ones, including detailed skills in the area of planning, and organizing evaluation of educational processes;

- communication-related ones, which are expressed in the effectiveness of linguistic behaviour in educational situations;

- cooperation-related ones, manifested in pro-social and integration behaviour;

- creative ones, thanks to which the teacher is capable of innovation and a creative approach to tasks;

- information technology-related ones, which, after mastering a foreign language and new technologies, allow the teacher to use modern sources of information;

- moral ones, constituting the basis for responsibility and professional ethics ${ }^{17}$.

Praxeological competence is expressed by the teacher's effectiveness in planning, completing, organizing, as well as controlling and evaluating educational processes. It manifests itself in the fact that the teacher is able to: a) develop their own curriculum; b) operationalize general aims of education and upbringing; c) program teaching contents; d) construct tests and other tools to measure stu-

14 R. Kwaśnica, Wprowadzenie do myślenia o nauczycielu, (in:) Pedagogika. Podręcznik akademicki, ed. Z. Kwieciński, B. Śliwerski, Państwowe Wydawnictwo Naukowe, Warsaw 2003, pp. 300-303.

15 After: J. Kuźma, Nauka o szkole. Studium monograficzne. Zarys koncepcji, Wydawnictwo Impuls, Cracow 2005, p. 195.

${ }^{16}$ K. Denek, Edukacja jutra, "Homines Hominibus" 1(4), 2008, pp. 5-15.

17 K. Denek, Kształcenie zawodowe nauczycieli w kontekście reformy edukacji, (in:) Problemy pedeutologii na przełomie XX i XXI wieku, ed. Z. Jasiński, T. Lewowicki, Wydawnictwo Uniwersytetu Opolskiego, Opole 2000, pp. 122-127. 
dent achievements; e) interpret and evaluate these achievements; f) use the results of examinations to modify the didactic work; g) build a school education program; h) individualize mental activity of students according to their abilities and talents; i) determine the reasons for school failure; $j$ ) identify threats related to various addictions; k) identify phenomena and typical forms of developmental disorders of a student and direct them to obtain appropriate help; 1) cooperate with parents; $m$ ) design a plan of own professional development ${ }^{18}$.

Communication-related competence of the teacher are manifested by the effectiveness of verbal and non-verbal behaviour in educational situations. A teacher with this competence knows how to: a) use verbal and non-verbal language in the work with students; b) arouse language sensitivity of students, revealing the values of cultural heritage and the functions of language as a tool of thinking and communication ${ }^{19}$.

Cooperation-related competence are associated with the skill to recognize the needs of students and the ability to cooperate in interpersonal relationships. This competence is manifested by the effectiveness of pro-social behaviour and the efficiency of teacher's integration activities ${ }^{20}$. The teacher becomes the initiator and partner of student actions, creates educational situations that involve students emotionally and intellectually, and trigger their specific activities $^{21}$.

Creative competence is the ability to self-education, innovation and unconventionality of activities combined with with adaptability, mobility and flexibility ${ }^{22}$ The concept of a creative teacher, who

18 W. Strykowski, J. Strykowska, J. Pielachowski, Kompetencje nauczyciela szkoły wspótczesnej, Wydawnictwo eMPi2,Poznań 2003, p. 27.

19 K. Denek, Edukacja jutra, "Homines Hominibus" 2008, no. 1(4), pp. 5-15.

${ }^{20}$ K. Denek, Edukacja jutra, “Homines Hominibus” 2008, no. 1(4), pp. 5-15.

${ }^{21}$ I. Żeber-Dzikowska, M. Wysocka-Kunisz, A. Szydłowska, Kompetencje nauczyciela w kontekście ksztatcenia, „Społeczeństwo. Edukacja. Język” 2016, no. 4, p. 96.

${ }^{22}$ K. Denek, Kompetencje nauczycieli w kontekście wyzwań XXI wieku i potrzeb reformy systemu edukacji w Polsce, (in:) Ksztatcenie pedagogiczne w dobie przemian eduka- 
shapes their professional personality by self-education, continuous improvement of qualifications, improvement of their own skill, participation in scientific and methodical research, undertaking innovative activities, and finally search for new areas and challenges in didactic and educational work, is described in the pedentological literature ${ }^{23}$. As K. Denek writes, a teacher with creative competence can creatively solve problems and think critically, as well as stimulate this kind of thinking in their students 24 .

Information technology-related competence is characterized by the ability to use information technology, including its use in teaching the subject. This competence is demonstrated by a teacher who is able to: a) skilfully choose and use media offers; b) read and analyse information contained in the media message; c) operate media devices; d) create multimedia presentations ${ }^{25}$. In addition, the teacher should know the basic principles of ergonomics of work with media in school settings and know at least one foreign language in order to be able to fully benefit from the scientific and cultural achievements of the modern world or develop their professional career ${ }^{26}$.

Moral competence is permanently inscribed in the ethos of the teaching profession. The teacher should be characterized by high moral standards.

In addition, didactic competence of a teacher should not be forgotten.

cyjnych w Polsce, ed. K. Wenta, Wydawnictwo Naukowe Uniwersytetu Szczecińskiego, Szczecin 2000, p. 39.

23 I. Żeber-Dzikowska, M. Wysocka-Kunisz, A. Szydłowska, Kompetencje nauczyciela w kontekście kształcenia, „Społeczeństwo. Edukacja. Język” 2016, no. 4, p. 97.

${ }^{24}$ K. Denek, Kompetencje nauczycieli w kontekście wyzwań XXI wieku i potrzeb reformy systemu edukacji w Polsce, (in:) Kształcenie pedagogiczne w dobie przemian edukacyjnych w Polsce, ed. K. Wenta, Wydawnictwo Naukowe Uniwersytetu Szczecińskiego, Szczecin 2000, p. 39.

25 I. Żeber-Dzikowska, M. Wysocka-Kunisz, A. Szydłowska, Kompetencje nauczyciela w kontekście kształcenia, „Społeczeństwo. Edukacja. Język” 2016, no. 4, p. 99.

${ }^{26}$ I. Żeber-Dzikowska, M. Wysocka-Kunisz, A. Szydłowska, Kompetencje nauczyciela w kontekście kształcenia, „Społeczeństwo. Edukacja. Język” 2016, no. 4, p. 99. 
The teacher's didactic competence relates to knowledge about the relevant principles, methods and forms of conducting the education process. First of all, the teacher should create conditions for independent learning, and conduct the learning process in various ways using a variety of teaching aids.

\section{Diagnostic and therapeutic process of a child with hearing impairment}

The World Health Organization (WHO) emphasizes that hearing impairment leads to selective disability, which, as a result of the lack of stimulation of psychomotor development and without specialized assistance, makes a person with hearing impairment acquire secondary disability, and not adapted to independent living. To prevent this, early revalidation should cover children from their birth to six years old. The organization of early care of a child with hearing impairment consists of three main levels: 1) diagnostic one (hospital, labour wards, neonatal centres, children's clinics), 2) diagnostic and revalidation one (specialist clinics, psychopedagogical clinics), 3) revalidation and education ones (kindergartens, schools) ${ }^{27}$.

The principles of early intervention are regulated in Polish legislation by the Regulation of the Minister of National Education of October 11, 2013. Early intervention applies mainly to those children who have been diagnosed with a hearing impairment during general screening. The test involves diagnosis of the neonate's hearing organ on the second day of life and on the day of discharge from the hospital. In addition to physical examination of the neonate's hearing organs, medical history is collected from the mother to determine risk factors for hearing impairment at a later stage. If factors are present, the child is subjected to periodic hearing control tests.

27 U. Eckert, Przygotowanie dziecka z wada stuchu do nauki szkolnej, WSiP, Warszawa 1986, p. 170. 
The first large-scale hearing screening was performed in 2001 as part of a newborn hearing screening program. In 2002, thanks to the "Great Orchestra of Christmas Charity" Foundation, which from its very beginning has been led by Jerzy Owsiak, the Newborn Universal Hearing Screening Program was introduced, based on global recommendations in this field, as hearing screening is the basic link in the early care and intervention program.

Children who have been diagnosed with hearing loss are subjected to the following actions:

- Provision, depending on the degree of hearing impairment, with a hearing aid or cochlear implant.

- Rehabilitation process aimed at the fullest possible reception of sounds.

- Psychological and pedagogical, speech therapy, therapeutic and specialist support depending on the individual needs of the child, within the time dimension and manner of implementation specified in the Act.

The aforementioned activities are called early intervention, although some suggest that it includes only activities provided by the health service, while the non-medical actions system should be called early support for child development ${ }^{28}$

However, it should be remembered that neither hearing aids nor cochlear implant restore hearing. They only create a chance to receive sounds and, after prolonged rehabilitation, "learn to hear" 29.

For several years, the so-called multi-interdisciplinary approach in the diagnosis and therapy of children with various disabilities has been discussed. Specialists work in a team consisting of, depending on the needs, physicians of various specialities, a psychologist, a physiotherapist, a speech and language therapist, an

${ }^{28}$ M. Sak, Decyzje specjalistów a osoby gtuche i stabostyszace, (in:) Sytuacja osób głuchych w Polsce. Raport zespotu ds. g/Głuchych przy Rzeczniku Praw Obywatelskich, Warsaw 2014, pp. 105-106.

${ }^{29}$ H. Skarżyński, Wskazania do wszczepów ślimakowych u dzieci, „Otolaryngologia Polska" no. 18/1994, pp. 154-157. 
occupational therapist, other therapists, a teacher, a social worker. Early, multispeciality, comprehensive and coordinated support should be understood as simultaneous, complementary medical, rehabilitation and therapeutic (early intervention), and rehabilitation and educational (early development support) interactions covered by one program, jointly developed, implemented and evaluated by properly prepared necessary specialists necessary for a given child.

Complexity should be understood in several ways as: a) combining medical, psychological and pedagogical diagnosis with indications of necessary rehabilitation and speech and language therapy; b) combining diagnosis with the development and performance of an individual rehabilitation and therapeutic program; c) combining the introduction of a rehabilitation and therapeutic program with its modification in connection with the achieved effects or their lack by an interdisciplinary team of specialists.

Comprehensive diagnosis and revalidation of the deaf are conducted by: speciality care clinics; rehabilitation clinics for children with hearing impairment under the auspices of the Polish Association of the Deaf; hearing and speech clinics of the Institute of Physiology and Pathology of Hearing; early intervention centres; early psychological and therapeutic help centres; diagnosis and therapy teams; psycho-pedagogical counselling centres ${ }^{30}$.

As mentioned above, specialists who have accompany the child from the moment of the diagnosis of hearing impairment are a deaf speech and language therapist and a deaf educator. Their high competence has an impact on the diagnostic and therapeutic process.

\section{Aim of the paper}

The development of education and rehabilitation, as well as the development of speech in a child with hearing impairment has been

30 G. Gunia, Terapia logopedyczna dzieci z zaburzeniami stuchu $i$ mowy, Impuls, Cracow 2006, p. 48. 


\section{described in many scientific papers in the field of both deaf educa- tion $^{31}$, and deaf speech and language therapy ${ }^{32}$. Numerous works in}

${ }^{31}$ Cf. e.g. K. Kirejczyk, Ewolucja systemów ksztatcenia dzieci głuchych, Wydawnictwo Nasza Księgarnia, Warsaw 1967; E. Nurowski, Surdopedagogika polska. Zarys historyczny, Państwowe Wydawnictwo Naukowe, Warsaw 1983; B. Hoffmann, Surdopedagogika, Państwowe Wydawnictwo Naukowe, Warsaw 1987; O. Périer, Dziecko z uszkodzonym narządem stuchu. Aspekty medyczne, wychowawcze, socjologiczne i psychologiczne, translated by T. Gałkowski, Wydawnictwa Szkolne i Pedagogiczne, Warsaw 1992; A. Rakowska, Rozwój systemu gramatycznego u dzieci głuchych, Wydawnictwo Naukowe Wyższej Szkoły Pedagogicznej, Cracow 1992; A. Korzon, Totalna komunikacja jako podejście wspomagające rozwój zdolności językowych uczniów głuchych, Wydawnictwo Naukowe Wyższej Szkoły Pedagogicznej, Cracow 2001; E. Kulczycka, Wychowanie stuchowo-werbalne dzieci $z$ wada stuchu w wieku przedszkolnym, Wydawnictwo Akademii Pedagogiki Specjalnej im. Marii Grzegorzewskiej, Warsaw 2004; U. Eckert, Pedagogika niestyszacych i niedostyszacych - surdopedagogika, (in:) Pedagogika specjalna, ed. W. Dykcik, Wydawnictwo Naukowe Uniwersytetu im. A. Mickiewicza, Poznań 2001; J. Zielińska, Edukacja dzieci z uszkodzeniem stuchu w spoteczeństwie informacyjnym, Wydawnictwo Adam Marszałek, Torun 2005; K. Krakowiak, Studia i szkice o wychowaniu dzieci z uszkodzeniami stuchu, Wydawnictwo Katolickiego Uniwersytetu Lubelskiego, Lublin 2006; A. Korzon, K. Plutecka, Kształcenie zintegrowane uczniów niestyszących w teorii i praktyce edukacyjnej, Wydawnictwo Impuls, Cracow 2010; D. Podgórska-Jachnik, Głusi - emancypacje, Wydawnictwo Naukowe Wyższej Szkoły Pedagogicznej, Łódź 2013; I. Chrzanowska, Pedagogika specjalna. Od tradycji do wspótczesności, Wydawnictwo Impuls, Cracow 2015; E. Woźnicka (ed.), Edukacja niesłyszacych: wczoraj, dziś i jutro, Wydawnictwo Akademii Humanistyczno-Ekonomicznej, Łódź 2017.

32 Cf. e.g. S. Grabias (ed.), Gtuchota a jezzyk, Wydawnictwo Uniwersytetu Marii Curie-Skłodowskiej, Lublin 1994; Z.M. Kurkowski, Przegląd metod kształcenia mowy dzieci z uszkodzonym stuchem, (in:) S. Grabias (ed.), Gtuchota i język, Wydawnictwo Uniwersytetu Marii Curie-Skłodowskiej, Lublin 1994; Z.M. Kurkowski, Mowa dzieci sześcioletnich z uszkodzonym narządem stuchu, Wydawnictwo Uniwersytetu Marii Curie-Skłodowskiej, Lublin 1996; J. Cieszyńska, Od słowa przeczytanego do wypowiedzianego. Droga nabywania systemu jezykowego przez dzieci niestyszące w wieku poniemowlęcym i przedszkolnym, Wydawnictwo Naukowe Akademii Pedagogicznej, Cracow 2000; G. Gunia, Terapia logopedyczna dzieci z zaburzeniami stuchu $i$ mowy, Wydawnictwo Impuls, Cracow 2006; Z.M. Kurkowski, Audiogenne uwarunkowania zaburzeń komunikacji językowej, Wydawnictwo Uniwersytetu Marii Curie-Skłodowskiej, Lublin 2012; E. Muzyka-Furtak (ed.), Surdologopedia. Teoria i praktyka, Wydawnictwo Harmonia Gdańsk 2015; D. Podgórska-Jachnik, Specyfika wczesnego wspomagania rozwoju $i$ wczesnej interwencji logopedycznej w pracy $z$ dziećmi $z$ uszkodzonym stuchem, (in:) Wczesna interwencja logopedyczna, ed. K. Kaczorowska-Bray, S. Milewski, Wydawnictwo Harmonia, Gdańsk 2016, pp. 459-496. 
the field of pedeutology have also been created (see chapter on the concept of competence). In these works, the issue of the deaf educator's and deaf speech and language therapist's competencies was discussed to a small extent (the exception is the work of K. Plutecka, cited above, Professional competence of a deaf educator... (Kompetencje zawodowe surdopedagoga...). The aim of the article is to discuss the competence of a deaf educator and a deaf speech and language therapist (a deaf speech and language therapy and a deaf speech and language therapy and education specialist). Competence are understood here in two ways: firstly, as the range of knowledge, skills and predispositions to practice the profession, and secondly, as the range of the qualifications to deal with specific tasks and make decisions related to them.

The aim is also to draw attention to the problem of the quality of training specialists in the field of diagnosis and therapy of children with hearing impairment. Care for the highest quality of education, and preparation of high-class specialists is one of the priorities of higher education.

The term child with hearing impairment is treated as superior to the terms adopted in scientific publications in the field of deaf education $^{33}$, i.e. the terms: a deaf, hard of hearing, hearing-impaired child and synonymous with the terms: a child with hearing defect, a child with hearing loss, a child with hearing disability.

${ }^{33}$ Currently, in the educational source literature, there are several terms used to describe a child with special educational needs, who requires deaf speech and language therapy support, namely: a child with hearing defect (e.g. U. Eckert, Przygotowanie dziecka z wada stuchu do nauki szkolnej, Wydawnictwa Szkolne i Pedagogiczne, Warsaw 1986; A. Korzon (ed.), Wychowanie stuchowe dzieci z wada stuchu, Wydawnictwo Intrograf, Katowice 1994), a child with hearing loss (e.g. B. Hoffmann, Surdopedagogika, Państwowe Wydawnictwo Naukowe, Warsaw 1987; Z.M. Kurkowski, Przegląd metod kształcenia mowy dzieci z uszkodzonym stuchem, (in:) Gtuchota i język, ed. S. Grabias, Wydawnictwo Uniwersytetu Marii Curie-Skłodowskiej, Lublin 1994), a deaf, hard of hearing, hearing-impaired child (np. B. Szczepankowski, Niestyszacy głusi - głuchoniemi. Wyrównanie szans, Wydawnictwa Szkolne i Pedagogiczne, Warsaw 1999), a child with hearing impairment (e.g. H. Skarżyński, M. Mueller-Malesińska, W. Wojnarowska, Klasyfikacja zaburzeń stuchu, „Logopedia” 2002, 28). 


\section{Competencies (range of knowledge, skills, predispositions) of a deaf educator and a deaf language and speech therapist}

\section{A. Competence of a deaf educator ${ }^{34}$ :}

1. Praxeological competence:

- people involved in the work with children and youth with hearing impairment must undergo an appropriate specialist training, or these are people with knowledge in the field of audiology, deaf child psychology, speech and language therapy, methods of activating the hearing analyser;

- a deaf educator is a specialist in three fields: deaf education, subject teaching and he knows sign language very well;

- they can choose the best teaching methods for their students, have a good organization of educational and rehabilitation work;

- they are effective in planning, organizing, performing, controlling and evaluating educational processes;

- they know and apply the principles of the deaf didactics: among others, they accept a student with hearing impairment, apply the principle of individualization, accurately inform students about tasks and requirements, grade difficulties;

- they have full contact with the deaf child;

- they take care of the development of speech and thinking of their students and proper attitude to students with hearing impairments;

- they encourage students to acquire knowledge on their own;

- they broaden their knowledge and skills through: knowledge of source literature, reading specialist literature, participation in professional development workshops or exchange of views with other teachers.

34 The following competencies are listed based on the work of K. Plutecka, Professional competencies of a deaf educator with hearing impairment (Kompetencje zawodowe surdopedagoga z wada stuchu), Wydawnictwo Impuls, Cracow 2006. 
2. Communication-related competence:

- they tend to use all available forms of communication to shape the language competence of the student with hearing impairment;

- they are very good at using bimodal or multimodal codes for communicating with the student with hearing defect;

- they easily establish a satisfactory dialogue with the student.

3. Cooperated-related competence:

- they understand the importance of constructive acceptance of the disability and the deaf subculture;

- they have the skills to build scenarios of various forms of cooperation constituting a form of solutions to problem situations in contacts between school and the environment;

- they have the skills to perform appropriate educational and rehabilitation activities among students with hearing defect;

- they know the principles and forms of cooperation between teachers and parents;

- they treat children with hearing defect with respect, treat them seriously and shows interest in their problems;

- they undertake appropriate educational and remedial actions in the case of children with behavioural and learning difficulties.

4. Creative competence:

- they have the skill to develop creative behaviour and independent thinking in children with hearing impairment;

- they encourage the creation of a positive "teaching" environment for individuals with hearing impairment;

- they teach children to think, solve problems and other logical strategies to fulfil their individual learning needs;

- they organise form teams, considering the level of students' abilities, develop effective, active and creative attitudes of students;

- they plan problem-based teaching encouraging the active participation of children in different groups and individually; 
- they develop their own creativity by, among others: training in creative methods, stimulating themselves to creativity, organizing their work, developing the ability to use the ideas of other people, educating themselves in cooperation with others, developing an attitude of positive thinking and acting, developing interpersonal and negotiating skills.

5. Information technology-related competence:

- a deaf educator has the skills to use new information technologies that can be part of their workshop and provide didactic help in teaching the subject;

- they have the skill to use terminology, means, software and methods in the field of information technology;

- they recognize the role of information technology as a teaching aid in teaching their field;

- they know and respects the legal, ethical and social aspects of access to and use of information technology;

- they use information technology to communicate with parents of students and in their own professional development.

6. Moral competence:

- a deaf educator has appropriate psychological predispositions, which lead to moral reflection, as well as evidence the ethical validation of the teacher's professional activities;

- they are moral authorities that restores the order and unambiguity of criteria to students with hearing defect.

In addition to the aforementioned competencies, A. Löwe ${ }^{35}$ distinguishes personal competencies, among which he lists the following predispositions necessary for effective work with a child with hearing impairment and their parents: patience, perseverance, sense of humour, good diction. In her research A. Korzon ${ }^{36}$ draws attention to such qualities as patience, kindness, perseverance, balance

35 A. Löwe, Każde dziecko może nauczyć się styszeć i mówić: wczesna diagnoza i wczesna rehabilitacja dziecka $z$ wada stuchu, translated by H. Ferens, Wydawnictwo Media Rodzina, Poznań 1999, p. 154.

36 A. Korzon, Osobowość pedagoga specjalnego, „Rocznik Naukowo-Dydaktyczny. Prace Pedagogiczne" 1986, vol. 100. 
and self-control. Surveys conducted by K. Plutecka ${ }^{37}$ demonstrate that the most desirable characteristics of a deaf educator include ${ }^{38}$ : patience, forbearance, empathy, determination, self-control, tolerance, kindness, thoroughness, discipline, selflessness, ability to establish contact, criticism, assertiveness, justice, sensitivity, diligence, ambition, flexibility of thinking, ability to organize work, ability to listen, personal culture, seriousness, punctuality, ease of adapting to other people, ability to help others, protectiveness, politeness.

B. Competencies of deaf speech and language therapist:

1. Praxeological competence:

- they know medical, psychological, educational and speech and language therapy aspects of hearing impairment, they know the consequences of hearing impairment in specific areas of child development;

- they know the classification of hearing impairment, the most common causes, mechanisms and clinical symptoms, as well as speech disorders caused by impaired hearing;

- they know the basic typologies related to hearing impairment in the context of speech development, language and communication competence;

- they can describe the linguistic and cognitive development of a child with impaired hearing and compare it with the correct language acquisition in a healthy child;

- they are able to assess the usefulness of various therapeutic techniques, speech and language therapy tests to perform tasks and solve problems of children with central hearing loss, are able to introduce these techniques and tests to the study;

- they can interpret the results of basic hearing tests;

- they know the applications of various forms of hearing aids in children;

${ }^{37}$ K. Plutecka, Kompetencje zawodowe surdopedagoga $z$ wada stuchu, Wydawnictwo Impuls, Cracow 2006, pp. 147-150, 163-168.

$38 \mathrm{~K}$. Plutecka lists them as moral competence. 
- they know the standards of the procedure in the case of diagnosis and deaf speech and language therapy;

- they are able to assess the possibility of auditory and visual perception of spoken statements of children with hearing impairment;

- they are able to perform the assessment of the linguistic, communication and cognitive development of children with hearing impairment;

- they are able to perform the assessment of the possibility of nonverbal communication of children with hearing impairment;

- they have knowledge about the basics of modern medical diagnostics important for speech and language diagnostics and therapy;

- they know the basics of diagnostics of complex cases of hearing impairment, have acquired the ability to assess selected clinical cases;

- they have the ability to program therapy for children with hearing impairment based on selected therapeutic strategies;

- they have the ability to prepare a program of auditory education/auditory training of a child with hearing impairment;

- they can develop auditory perception and linguistic skills in children, and remove reading and writing difficulties caused by central hearing impairment;

- they know how to create communication aids, adapt them to the current needs and capabilities of a child with hearing impairment;

- they have the ability to control, document the course and effectiveness of speech and language therapy, verify diagnostic hypotheses, modify the goals and methods of therapy;

- they have the ability to create a speech and language therapy opinion for an educational institution and for a team adjudicating on the need to provide a child with necessary rehabilitation, educational, financial resources, etc.;

- they have knowledge about the possibilities of teaching in ordinary schools, integrated classes and special schools for children and youth with hearing impairments; 
- they have knowledge about the impact of hearing disorders on the education and upbringing of children and youth with hearing damage;

- they have the ability to prepare parents and teachers to support the child's linguistic development in terms of communication and cognition;

- they are able to assess the usefulness and purposefulness of using speech and language therapy diagnosis methods and therapeutic techniques;

- they have the ability to assess the progress in the rehabilitation of hearing, voice and speech of children with hearing impairment;

- they have knowledge in the field of scientific research on disorders and are able to use it in therapeutic practice;

- they understand the need for continuous professional training and personal development, they use foreign language literature to acquire knowledge.

2. Communication-related competence:

- they have knowledge about the principles of building therapeutic contact with hard of hearing and deaf children;

- they know how to establish contact with children with hearing impairment and their guardians;

- they are able to communicate using various communication and information channels and techniques with specialists in the field of, among others, audiology, phoniatrics, otorhinolaryngology.

3. Cooperated-related competence:

- can cooperate with a child with hearing impairment, showing them respect and understanding;

- can cooperate with an audiologist, laryngologist, deaf psychologist, deaf educator, neurologist to make a full diagnosis and discuss the therapy program.

4. Creative competence:

- they have the ability to develop a program of procedure tailored to the needs and capabilities of the child, considering the results of multispeciality examinations; 
- they have the ability to incorporate a deaf speech and language therapy program into the procedures of multispeciality treatment of a child with hearing impairment.

5. Information technology-related competence:

- they know the possibilities of supporting children with hearing impairment by low and high technology aids;

- they have knowledge of computer programs for the deaf speech and language therapy diagnosis and rehabilitation.

6. Moral competence:

- they know the ethical principles and standards related to practising the profession of a deaf speech and language therapist;

- they know that the confidentiality and respect for privacy and all rights of the child with hearing impairment as a patient must be respected;

- they place the benefit of the patient on the first position;

- they respect the dignity of a child with hearing impairment, their abilities, needs and limitations.

\section{Competencies (range of qualifications) of a deaf educator and a deaf speech and language therapist}

A. Competence of a deaf educator:

A deaf educator:

- makes a psychopedagogical and functional diagnosis of children and youth with hearing impairment;

- organizes and describes individual educational facts related to a child with hearing impairment;

- explains and designs changes in didactic and educational reality;

- takes care of the correctness of the upbringing and teaching process;

- creates an educational environment in which every child has a sense of security, care and respect, can freely and without inhibition express their needs and feelings; 
- prevents the development of deficits and dysfunctions and the adverse impact of deafness on the child's developmental potential;

- prepares their students to live in an environment of hearing people;

- is qualified for diagnostic, educational and therapeutic work with a child with hearing impairment;

- designs and implements individual and group revalidation programs and introduces various methods of working with children with hearing impairment;

- improves cognitive processes that are impaired by the reduction of perception of auditory stimuli, including verbal speech;

In addition, a deaf educator is entitled to:

- initiate and coordinate interdisciplinary measures to support a child with hearing impairment;

- offer advice and constant support in educational matters to parents;

- provide other teachers and institutions with advice and constant support concerning further child's education and even choice of profession;

- undertake a cooperation with a broadly understood specialist community (a deaf speech and language therapist, a therapist).

B. Competencies of deaf speech and language therapist:

A speech and language therapist:

- examines and analyses factors affecting the pace and quality of speech learning by children with hearing impairment;

- diagnoses hearing impairment, linguistic attitudes and difficulties as well as communication behaviours of children with hearing impairment and disorders based on interviews with parents, examination of the child, observation of their behaviour, etc.;

- diagnoses developmental needs (primarily communicationrelated needs) of a child with hearing impairment; 
- plans the rehabilitation of hearing and speech of children with hearing impairment based on the diagnosis, develops strategies of the speech and language therapy procedure;

- conducts speech and language therapy aimed at diverse groups of children with hearing impairment (depending on the degree of hearing impairment, age, achieved level of functioning, individual needs and possibilities, as well as social and environmental situation) using modern methods and techniques of work;

- conducts training that stimulates, improves auditory perception (auditory control, auditory analysis and synthesis, auditory memory) and pronunciation; speech understanding exercises (words, phrases, simple and complex sentences);

- conducts stimulation of speech expression (repetition, naming, dialogue and narrative speech);

- stimulates cognitive processes in the field of visual, sensory perception, spatial orientation, attention, memory, cause and effect and abstract thinking;

- conducts classes developing the ability to understand and create verbal statements, or to acquire language and communication skills in children with various hearing disorders;

- conducts classes in the field of acquisition of reading and writing skills by children with various hearing disorders;

- conducts classes developing psychomotor and cognitive functions;

- introduces elements of supportive and alternative methods, conducts non-verbal communication exercises (e.g. gesture, facial expressions, fingerspelling);

- shapes appropriate attitudes and behaviours in parents (guardians) of children and youth with hearing impairment;

- carries out preventive activities in the field of eliminating factors that lead to hearing impairment (e.g. listening to loud music);

- cooperates with members of a multispeciality medical and rehabilitation, as well as adjudicating team. 
In addition, a deaf speech and language therapist is entitled to:

- prepare a written deaf speech and language therapy opinion on the results of deaf speech and language therapy diagnosis of children and youth with hearing impairment and/or dysfunction;

- formulate written and oral recommendations based on deaf speech and language therapy diagnosis on how to proceed in other health care and educational facilities attended by children and youth with impairment and/or dysfunctions of the auditory system, who experience disorders in the development and/or course of verbal communication;

- indicate specialist examinations necessary for making deaf speech and language therapy diagnosis;

- cooperate with other specialists in the process of diagnosing and improving children and youth with hearing impairment and/or dysfunctions, who experience disorders in the development and/or course of verbal communication;

- consult and instruct the child's family and relatives about the recommended methods and forms of speech therapy and prognosis;

- participate in committees and teams adjudicating on the need for special (early support teams, rehabilitation and special care centres) and social (benefits, treatment and rehabilitation services) services depending on the age of the patient and the adjudicating institution 39

\section{Deaf educator and deaf speech and language therapist in the modern education and rehabilitation system}

The Classification of Occupations and Specializations prepared by the Department of Labour Market of the Ministry of Family, La-

${ }^{39}$ Cf. Program specjalizacji w surdologopedii, Warsaw 2010 www.cmkp.edu.pl/ wp-content/uploads/2013/07/surdologopedia-2010.pdf. 
bour and Social Policy, published on April 29, 2014, modified on February 12, 2019, lists two aforementioned profession, or the profession of a deaf and hard of hearing teacher (deaf educator) (code 235201) and a deaf speech and language therapist (code 229404). According to the classification, a deaf and hard of hearing teacher: conducts didactic and educational, as well as care providing classes with deaf children and youth in: kindergartens, primary schools, junior high schools, upper secondary schools and school and education centres for the deaf, using hearing aids, sign language, finger alphabet and sound speech, in order to teach them knowledge and skills provided in the curriculum; prepares deaf students to fully participate in life among hearing people. Their professional tasks include: conducting didactic and educational, as well as care providing classes as part of general education subjects provided in the curriculum, such as Polish language, art, history, geography, biology with hygiene, mathematics, physics, etc.; conducting various types of individual revalidation, such as: didactic-compensatory classes, remedial classes aimed at eliminating defects and disorders of speech and its improvement, as well as classes aimed at eliminating postural defects and improving physical fitness; planning the didactic and educational process as part of the taught subject (developing content distribution, adapting content to students' abilities), developing syllabuses; planning and preparing teaching aids (illustrations, charts, models, labels, films, video cassettes, etc.) necessary to present the content of education within a given subject; developing tools to measure students' achievement; diagnosing students' school achievements and skilful prevention of failures; creating conditions for the participation of students in various forms of socio-cultural activity and self-governance; introducing students to independent work, developing their interests, shaping desirable attitudes, promoting activity of deaf students in social, cultural and recreational work; fulfilling the duties of a form master, care for the general level of the educated group, speech development, socialization, discipline, students' reading habits and activity of student organizations; applying various forms of care to students 
and taking actions to improve the material and educational conditions of deaf children; cooperating with parents of deaf students and encouraging them to cooperate for the benefit of the form and school; reasonable organizing of deaf students' free time; undertaking actions aimed at proper school and professional orientation of students; improving qualifications by participating in various forms of improvement and self-education ${ }^{40}$.

In turn, a deaf speech and language therapist, in accordance with the record in the classification: performs specialized tests, analyses their results, makes a diagnosis of people with hearing impairment and disorders; conducts rehabilitation and speech improvement therapy: articulation, breathing, auditory exercises, lip reading, etc. in the rehabilitation clinics of the Polish Association of the Deaf, phoniatric clinics, otorhinolaryngology wards, sanatoriums, schools and kindergartens, as well as centres for children with hearing impairment. Their tasks include: examination and analyse of factors affecting the pace and quality of speech learning by children with hearing impairment; diagnosing hearing impairment, linguistic attitudes and difficulties as well as communication behaviours of children with hearing impairment and disorders based on interviews with parents, examination of the child, observation of their behaviour, etc.; planing the rehabilitation of hearing and speech of deaf or hard of hearing people based on the diagnosis; conducting speech and language therapy for children and youth, as well as adults with hearing impairment and disorders consisting in performing breathing and auditory exercises as well as learning and understanding words, sentences and expressions; developing the skill of reading and writing; conducting classes aimed at improving auditory perception and pronunciation; cooperating with otolaryngologists and clinics of the Polish Association of the Deaf; shaping appropriate attitudes and behaviours in parents (guardians) of children and youth with hearing impairment; documenting examinations, diagnoses and prevention, as well as therapeutic activity; car-

40 (http:/ / psz.praca.gov.pl/rynek-pracy/bazy-danych/klasyfikacja-zawodowi-specjalnosci/wyszukiwarka-opisow-zawodow//-/klasyfikacja_zawodow). 
rying out preventive activities in the field of eliminating factors that lead to hearing impairment (e.g. listening to loud music); participating in training in the field of deaf speech and language therapy. Additionally, they can: conduct scientific, didactic and training activities for deaf educators and speech and language therapists; publish research results and professional experience; ensure provision of hearing aids to hearing impaired children ${ }^{41}$.

Education preparing and entitling to work with people with hearing impairment can be received at the bachelor's and supplementary master's studies, as well as postgraduate studies in deaf education, deaf speech and language therapy and less often special education. Such studies are offered by renowned state universities, cf. full-time and extramural master's studies, as well as uniform master's studies in the field of special education, specialization in deaf education: the Maria Grzegorzewska University in Warsaw; postgraduate studies in deaf education: Adam Mickiewicz University in Poznan, the Maria Grzegorzewska University in Warsaw, Pedagogical University of Krakow, Kazimierz Wielki University in Bydgoszcz; postgraduate studies in deaf speech and language therapy; Maria Curie-Skłodowska University in Lublin, University of Gdańsk, Adam Mickiewicz University in Poznan, the University of Silesia in Katowice.

The report of the team for the $\mathrm{d} /$ Deaf at the Polish Ombudsman published in 2014 draws attention to the following issues regarding the education of high-class specialists to work with people with hearing impairment: study programs focus mainly on issues of rehabilitation, correction of speech defects and issues of social integration and deaf education. They lack topics related to the deaf culture, sign language, the deaf identity as a language minority, and many other matters relevant to this environment ${ }^{42}$.

41 (http:/ / psz.praca.gov.pl/rynek-pracy/bazy-danych/klasyfikacja-zawodowi-specjalnosci/wyszukiwarka-opisow-zawodow//-/klasyfikacja_zawodow).

42 M. Sak, Decyzje specjalistów a osoby głuche i stabostyszace, (in:) Sytuacja osób głuchych w Polsce. Raport zespołu ds. g/Gtuchych przy Rzeczniku Praw Obywatelskich, Warsaw 2014, p. 109. 
To meet certain demands, some universities open postgraduate studies in Polish Sign Language ${ }^{43}$ (cf. e.g. Polish Sign Language at the University of Warsaw), at some postgraduate studies such subjects as sign language basics, bilingual education, work with family are introduced (cf. Deaf Speech and Language Education at the Adam Mickiewicz University in Poznań).

The education quality committees operating at universities, as well as the Ministry of Science and Higher Education oblige people responsible for conducting study majors and postgraduate studies to introduce high standards of education. The problem of ensuring highquality education during studies was highlighted in several strategic documents in the area of higher education, including the Development strategy for the higher education system in Poland up to the year 2020 ("Strategia Rozwoju Szkolnictwa Wyższego do 2020 r.") 44.

Deaf educators and deaf speech and language therapists, as highly qualified specialists, can find employment in educational and rehabilitation facilities and other facilities supporting people with hearing impairment, or in: education and upbringing institutions (kindergartens, special, integrated and public primary schools, school and education centres for the deaf and hard of hearing, boarding schools); speciality care clinics, including psychological and pedagogical counselling centres, the Polish Deaf Association counselling centres; care, upbringing and rehabilitation facilities; social and health care facili-

${ }^{43} \mathrm{~A}$ milestone has been the enactment of the Act on sign language and other forms of communication (Act of 19 August 2011 on sign language and other means of communication (Journal of Laws of 2011, No. 209, item 1243, as amended, hereinafter also: the Act on Sign Language), whose main goal is to ensure an adequate level of support for people with hearing impairment and to enable them to overcome barriers in communication with public institutions, emergency and intervention services and health care institutions. This Act is also the first universally binding legal act in Poland, which explicitly emphasizes the right of deaf and deafblind people to communicate using freely selected non-verbal communication methods.

${ }^{44}$ Report entitled. „Strategia rozwoju szkolnictwa wyższego w Polsce do 2020 roku - wariant drugi" was prepared by the consortium Ernst \& Young Business Advisory and the Institute for Market Economics in March 2010, www.nauka. gov.pl/g2/ oryginal/2013_05/59579f9e6efaec82014d6d5be081ca23.pdf 
ties; early intervention centres; facilities with early support teams; educational local government agencies; non-governmental organizations working for the benefit of the disabled.

\section{Summary}

Children with hearing impairment behave differently than their healthy peers. Problems and limitations mainly concern: a) communication, making it difficult to satisfy needs and exchange information with others, get to know oneself and the surrounding social reality, order the world by naming objects, phenomena, events, determining their characteristics and relationships between them; b) learning about reality and phenomena, understanding concepts; c) the emotional sphere, connected with the acceptance of own disability and limitations, as well as shaping the image of oneself, and undertaking social interactions; d) social contacts and interpersonal relationships ${ }^{45}$.

The consequence of hearing loss are psychological and social behavioural disorders. Without affecting the physical, and potentially also mental capacity of the child, impairment of the hearing organ impedes and limits their social contacts, generally creating situations in which a child suffering from this disability is to some degree isolated from the environment. This becomes the cause of significant educational, didactic and rehabilitation problems.

Teaching, upbringing and rehabilitating a child with a hearing impairment is a complex problem. The wide and varied form of rehabilitation of such a child requires close cooperation between many specialists. Well conducted rehabilitation favours the teaching process, and the correct teaching course favours the rehabilitation process.

The expectations concerning the competence of an ideal deaf educator and deaf speech and language therapist are very high.

${ }^{45}$ B. Ciupińska, Dziecko z wada stuchu w roli ucznia, "Konteksty Pedagogiczne” 2(7)/2016, p. 148. 
They should possess extensive general and specialist knowledge and constantly improve their skills in this field. They should also be able to practically apply the methodology of work in an effective manner, which guarantees the achievement of teaching success. They should also set an example for children and youth, as well as be able to establish contact with them. Finally, they are required to have a high ethical level and personality traits that guarantee commitment to the profession and resistance to stressful situations ${ }^{46}$.

Thanks to reliable implementation of educational challenges and teachers' involvement, it is possible to prepare a disabled (deaf or hard of hearing) child to function independently in adult life ${ }^{47}$.

Currently, in deaf education, tendencies of the search for various organizational forms, methods and means in order to make the best use of all opportunities that provide a child with hearing impairment with comprehensive development, are visible ${ }^{48}$.

The environments associated with people with hearing impairment emphasize that:

In the field of preparation of specialists dealing with issues related to deaf and hard of hearing people, little has changed for several decades. The vast majority of deaf educators, deaf speech and language therapists and psychologists represent the medical approach to deaf people and place the necessity of auditory rehabilitation of a deaf person in the first position as a prerequisite for their proper rehabilitation, as well as rejects the possibility of using sign language as a form of communication with a deaf child. However, life practice shows that the effects of choosing such a path do not always bring measurable benefits ${ }^{49}$.

46 I. Żeber-Dzikowska, M. Wysocka-Kunisz, A. Szydłowska, Kompetencje nauczyciela w kontekście kształcenia, "Społeczeństwo. Edukacja. Język” 2016, no. 4, p. 99.

${ }^{47}$ B. Ciupińska, Dziecko z wadq stuchu w roli ucznia, "Konteksty Pedagogiczne” 2(7)/2016, p. 148.

48 I. Jagoszewska, Rola rodziców w rozwoju dziecka niestyszaccego, ,'Wychowanie w Rodzinie" 2011, vol. 4, p. 54.

${ }^{49}$ A. Butkiewicz, M. Czajkowska-Kisil, Gtusi i nie(do)styszący na uczelni wyższej, (in:) Sytuacja osób głuchych w Polsce. Raport zespotu ds. g/Głuchych przy Rzeczniku Praw Obywatelskich, Warsaw 2014, pp. 33-34. 
They postulate that the process of educating people who will participate in the diagnostic and therapeutic process, or deaf educators and deaf speech and language therapists, should include sign language learning, subjects covering therapeutic methods from the point of view of special education, and not medicine (audiology), and finally subjects preparing specialists to work with parents of a child with hearing impairment ${ }^{50}$.

An educational offer that meets the aforementioned postulates is proposed to students by organizers of postgraduate studies in deaf education and deaf speech and language therapy conducted at the Faculty of Educational Studies of the Adam Mickiewicz University in Poznań.

\section{Bibliography}

Butkiewicz A., Czajkowska-Kisil M., Gtusi i nie(do)styszący na uczelni wyższej, (in: Sytuacja osób głuchych w Polsce. Raport zespotu ds. g/Głuchych przy Rzeczniku Praw Obywatelskich, Warsaw 2014, p. 28-35.

Chrzanowska I., Pedagogika specjalna. Od tradycji do wspótczesności, Wydawnictwo Impuls, Cracow 2015.

Cieszyńska J., Od stowa przeczytanego do wypowiedzianego. Droga nabywania systemu jezykowego przez dzieci niestyszace $w$ wieku poniemowlęcym $i$ przedszkolnym, Wydawnictwo Naukowe Akademii Pedagogicznej, Cracow 2000.

Ciupińska B., Dziecko $z$ wada stuchu w roli ucznia, "Konteksty Pedagogiczne" 2(7)/2016, p. 139-150.

Czajkowska-Kisil M., Siepkowska A., Sak M., Edukacja głuchych w Polsce, (in:) Sytuacja osób głuchych w Polsce. Raport zespotu ds. g/Głuchych przy Rzeczniku Praw Obywatelskich, Warsaw 2014, p. 13-27.

Czerepaniak-Walczak M., Aspekty i źródta profesjonalnej refleksji nauczyciela, Wydawnictwo Edytor, Torun 1997.

Denek K., Edukacja jutra, “Homines Hominibus” no. 1(4), 2008, p. 5-15.

Denek K., Kompetencje nauczycieli w kontekście wyzwań XXI wieku i potrzeb reformy systemu edukacji w Polsce, (in:) Ksztatcenie pedagogiczne w dobie przemian eduka-

${ }^{50}$ M. Czajkowska-Kisil, A, Siepkowska, M. Sak, Edukacja głuchych w Polsce, (in:) Sytuacja osób głuchych w Polsce. Raport zespołu ds. g/Gtuchych przy Rzeczniku Praw Obywatelskich, Warsaw 2014, pp. 13-27. 
cyjnych w Polsce, ed. K. Wenta, Wydawnictwo Naukowe Uniwersytetu Szczecińskiego, Szczecin 2000, p. 29-45.

Denek K., Kształcenie zawodowe nauczycieli w kontekście reformy edukacji, (in:) Problemy pedeutologii na przełomie XX i XXI wieku, ed. Z. Jasiński, T. Lewowicki, Wydawnictwo Uniwersytetu Opolskiego, Opole 2000, p. 121-130.

Dudzikowa M., Kompetencje autokreacyjne - czy $i$ jak sa możliwe do nabycia w toku studiów pedagogicznych, (in:) Ewolucja tożsamości pedagogiki, ed. H. Kwiatkowska, Wydawnictwo IHNOiT, Warsaw 1994, p. 199-212.

Dylak S., Wizualizacja w ksztatceniu nauczycieli, Wydawnictwo Naukowe Uniwersytetu im. A. Mickiewicza, Poznań 1995.

Eckert U., Przygotowanie dziecka z wadą stuchu do nauki szkolnej, Wydawnictwa Szkolne i Pedagogiczne, Warsaw 1986.

Eckert U., Pedagogika niestyszacych i niedostyszacych - surdopedagogika, (in:) Pedagogika specjalna, ed. W. Dykcik, Wydawnictwo Naukowe Uniwersytetu im. A. Mickiewicza, Poznań 2001, p. 167-179.

Grabias S. (ed.), Gtuchota a jezyk, Wydawnictwo Uniwersytetu Marii CurieSkłodowskiej, Lublin 1994.

Gunia G., Terapia logopedyczna dzieci z zaburzeniami stuchu i mowy, Wydawnictwo Impuls, Cracow 2006.

Hamer H., Klucz do efektywności nauczania. Poradnik dla nauczycieli, Wydawnictwo Veda, Warsaw 1994, p. 25-125.

Hoffmann B., Surdopedagogika, Państwowe Wydawnictwo Naukowe, Warsaw 1987.

Hyżak D., Kompetencje $i$ umiejętności nauczycieli wobec wyzwań XXI wieku, (in:) Edukacja jutra. XI Tatrzańskie Seminarium Naukowe, ed. F. Bereźnicki, K. Denek, Wydawnictwo Uniwersytetu Szczecińskiego, Szczecin 2005, p. 297-301.

Jagoszewska I., Rola rodziców w rozwoju dziecka niestyszącego, "Wychowanie w Rodzinie" 2011, vol. 4, p. 49-62.

Kirejczyk K., Ewolucja systemów kształcenia dzieci głuchych, Wydawnictwo Nasza Księgarnia, Warsaw 1967.

Kopaliński W., Stownik wyrazów obcych $i$ zwrotów obcojęzycznych z almanachem, Wydawnictwo Świat Książki, Warsaw 2000.

Korzon A., Osobowość pedagoga specjalnego, "Rocznik Naukowo-Dydaktyczny. Prace Pedagogiczne VI" vol. 100, 1986, p. 217-236.

Korzon A., Efektywny surdopedagog w opinii nauczycieli i uczniów z wada stuchu, (in:) Pedagogika specjalna wobec zagrożeń i wyzwań XXI wieku: materiały z obrad XVI sekcji III Zjazdu Pedagogicznego w Poznaniu (21-23 September 1998), ed. J. Pańczyk, W. Dykcik, Wydawnictwo Naukowe Uniwersytetu im. A. Mickiewicza, Poznań 1999, p. 188-195.

Korzon A., Totalna komunikacja jako podejście wspomagające rozwój zdolności językowych uczniów głuchych, Wydawnictwo Naukowe Wyższej Szkoły Pedagogicznej, Cracow 2001. 
Korzon A., Plutecka K., Kształcenie zintegrowane uczniów niestyszących w teorii i praktyce edukacyjnej, Wydawnictwo Impuls, Cracow 2010.

Korzon A. (ed.), Wychowanie stuchowe dzieci z wada stuchu, Wydawnictwo Intrograf, Katowice 1994.

Krakowiak K., Studia i szkice o wychowaniu dzieci z uszkodzeniami stuchu, Wydawnictwo Katolickiego Uniwersytetu Lubelskiego, Lublin 2006.

Kulczycka E., Wychowanie stuchowo-werbalne dzieci $z$ wada stuchu w wieku przedszkolnym, Wydawnictwo Akademii Pedagogiki Specjalnej im. Marii Grzegorzewskiej Warsaw 2004.

Kurkowski Z.M., Przeglad metod ksztatcenia mowy dzieci z uszkodzonym stuchem, (in: Gtuchota $i$ jezzyk, ed. S. Grabias, Wydawnictwo Uniwersytetu Marii Curie-Skłodowskiej, Lublin 1994, p. 67-90.

Kurkowski Z.M., Mowa dzieci sześcioletnich z uszkodzonym narządem stuchu, Wydawnictwo Uniwersytetu Marii Curie-Skłodowskiej, Lublin 1996.

Kurkowski Z.M., Audiogenne uwarunkowania zaburzeń komunikacji językowej, Wydawnictwo Uniwersytetu Marii Curie-Skłodowskiej, Lublin 2012.

Kuźma J., Nauka o szkole. Studium monograficzne. Zarys koncepcji, Wydawnictwo Impuls, Cracow 2005.

Kwaśnica R., Wprowadzenie do myślenia o nauczycielu, (in:) Pedagogika. Podręcznik akademicki, ed. Z. Kwieciński, B. Śliwerski, Państwowe Wydawnictwo Naukowe, Warsaw 2003, p. 291-323.

Löwe A., Każde dziecko może nauczyć się styszeć $i$ mówić: wczesna diagnoza $i$ wczesna rehabilitacja dziecka z wada stuchu, translated by: H. Ferens, Wydawnictwo Media Rodzina, Poznań 1999.

Muzyka-Furtak E. (ed.), Surdologopedia. Teoria i praktyka, Wydawnictwo Harmonia. Gdańsk 2015.

Nurowski E., Surdopedagogika polska. Zarys historyczny, Państwowe Wydawnictwo Naukowe Warsaw 1983.

Périer O., Dziecko z uszkodzonym narządem stuchu. Aspekty medyczne, wychowawcze, socjologiczne i psychologiczne, translated by T. Gałkowski, Wydawnictwo Szkolne i Pedagogiczne, Warsaw 1992.

Plutecka K., Kompetencje zawodowe surdopedagoga z wada stuchu, Wydawnictwo Impuls, Cracow 2006.

Podgórska-Jachnik D., Głusi - emancypacje, Wydawnictwo Naukowe Wyższej Szkoły Pedagogicznej, Łódź 2013.

Podgórska-Jachnik D., Specyfika wczesnego wspomagania rozwoju i wczesnej interwencji logopedycznej w pracy z dziećmi z uszkodzonym stuchem, (in:) Wczesna interwencja logopedyczna, ed. K. Kaczorowska-Bray, S. Milewski, Wydawnictwo Harmonia, Gdańsk 2016, p. 459-496.

Program specjalizacji w surdologopedii, 2010, Warsaw <www.cmkp.edu.pl/wp-con tent/uploads/2013/07/surdologopedia-2010.pdf [access on 01 December 2018]. 
Rakowska A., Rozwój systemu gramatycznego u dzieci głuchych, Wydawnictwo Naukowe Wyższej Szkoły Pedagogicznej, Cracow 1992.

Sak M., Decyzje specjalistów a osoby głuche i stabostyszace, (in:) Sytuacja osób głuchych w Polsce. Raport zespotu ds. g/Głuchych przy Rzeczniku Praw Obywatelskich, Warsaw 2014, p. 104-113.

Skarżyński H., Wskazania do wszczepów ślimakowych u dzieci, “Otolaryngologia Polska" no. 18/1994, p. 154-157.

Skarżyński H., Mueller-Malesińska M., Wojnarowska W., Klasyfikacja zaburzeń stuchu, "Logopedia" vol. 28, 2002, p. 91-116.

Stech K., Kompetencje zawodowe nauczyciela - spojrzenie na problem, (in:) Kompetencje nauczyciela-wychowawcy, ed. K. Ferenz, E. Kozioł, Wydawnictwo Naukowe Uniwersytetu Zielonogórskiego, Zielona Góra 2002, p. 11-20.

Strykowski W., Strykowska J., Pielachowski J., Kompetencje nauczyciela szkoty wspótczesnej, Wydawnictwo eMPi2, Poznań 2003.

Szczepankowski B., Niestyszący - głusi - głuchoniemi. Wyrównanie szans, Wydawnictwa Szkolne i Pedagogiczne, Warsaw 1999.

Woźnicka E. (ed.), Edukacja niestyszacych: wczoraj, dziś i jutro, Wydawnictwo Akademii Humanistyczno-Ekonomicznej, Łódź 2017.

Zielińska J., Edukacja dzieci z uszkodzeniem stuchu w spoteczeństwie informacyjnym, Wydawnictwo Adam Marszałek, Toruń 2005.

Żeber-Dzikowska I., Wysocka-Kunisz M., Szydłowska A., Kompetencje nauczyciela w kontekście kształcenia, "Społeczeństwo. Edukacja. Język" no. 4, 2016, p. 93-101. 